\title{
LONDON REVIEW OF EDUCATION
}

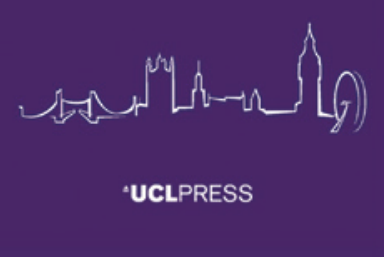

e-ISSN: $1474-8479$

Journal homepage:

https://www.uclpress.co.uk/pages/london-review-ofeducation

\section{Teachers as researchers: Reflecting on the challenges of research-practice partnerships between school and university in Chile}

\author{
Gonzalo R. Guerrero-Hernández (iD) and Rocío A. Fernández-Ugalde(iD
}

\section{How to cite this article}

Guerrero-Hernández, G.R. and Fernández-Ugalde, R.A. (2020) 'Teachers as researchers: Reflecting on the challenges of research-practice partnerships between school and university in Chile'. London Review of Education, 18 (3), 423-38. https://doi. org/10.14324/LRE.18.3.07

Submission date: 31 January 2020

Acceptance date: 12 May 2020

Publication date: 13 November 2020

\section{Peer review}

This article has been peer-reviewed through the journal's standard double-blind peer review, where both the reviewers and authors are anonymized during review.

\section{Copyright}

(c) 2020 Guerrero-Hernández and Fernández-Ugalde. This is an open-access article distributed under the terms of the Creative Commons Attribution Licence (CC BY) 4.0 https:// creativecommons.org/licenses/by/4.0/, which permits unrestricted use, distribution and reproduction in any medium, provided the original authors and source are credited.

\section{Open access}

The London Review of Education is a peer-reviewed open-access journal. 


\title{
Teachers as researchers: Reflecting on the challenges of research-practice partnerships between school and university in Chile
}

\author{
Gonzalo R. Guerrero-Hernández* - UCL Institute of Education, UK and \\ Universidad de Santiago de Chile \\ Rocío A. Fernández-Ugalde - University of Cambridge, UK and \\ Universidad de Santiago de Chile
}

\begin{abstract}
Teachers have tended to be underestimated as experts of their own practice and relegated to a technical role. In this context, action research appears as a form to legitimate teachers as active agents and producers of educational knowledge. This article aims to examine how a collaborative research-practice partnership between schools and universities in Chile fosters teachers' role as researchers. It adopts a qualitative methodology based on thematic analysis of data collected from questionnaires and focus groups. In particular, it reports perceptions of inservice teacher researchers who conducted research projects between 2016 and 2017 as a part of a researcher-practitioner partnership strategy implemented by a university in Chile. The findings suggest that the partnerships were highly valued among teachers because the partnerships allowed them to develop pedagogical reflection towards the improvement of their practices and required particular awareness and recognition of roles and the relationships between practical and theoretical knowledge. Finally, possibilities for strengthening teachers' role as researchers and collaborative research are presented at the end of the article.
\end{abstract}

Keywords: research-practice partnership, teachers as researchers, collaborative research, school-university relationship

\section{Introduction}

One of the main purposes of educational research has been to produce knowledge for improving education practices inside schools and classrooms (OEI, 2015). However, even though teachers are crucial for achieving better teaching and learning processes, they are usually underestimated as active agents and protagonists of their own practice (Kincheloe, 2003; Biesta, 2017). Rather, they are often viewed as a means for implementing policies and research findings that preserve a technical conceptualization of their role (Schön, 1987; Gandin and Gomes de Lima, 2015). This has resulted in a problematic issue from different positions; policymakers and educational authorities have observed with concern how some policy efforts tend to fail or have unexpected outcomes (OEI, 2015). University researchers have aimed to support teachers to incorporate educational findings into their classrooms, but they have not been able to produce pertinent knowledge from teachers' perspectives (Pesti et al., 2018). Consequently, in-service teachers perceive research as an area distant from their classroom practice, and even as irrelevant to their daily practice (Beycioglu et al., 2010). 
Critical pedagogues and scholars address this problem from a more complex perspective on the nature of teachers' work as creative, research-based and transformative (Freire, 1970; Giroux, 1988). For Kincheloe (2003), inquiry is an inherent dimension of teaching, and teacher research has the potential to foster teachers' empowerment. These critical perspectives have sparked many new initiatives on teacher research, and continue to be a pertinent lens to address issues of empowering teachers and enriching teaching and learning process in the classrooms (McLaughlin and Black-Hawkins, 2007). But even though there have been many successful research studies conducted by teachers that point to benefits for teachers' professional development and meaningful research findings, some scholars such as CochranSmith and Lytle (1999), Kincheloe (2003) and Cloonan (2019) have pointed out that practitioner research tends to be subject to critique, since it challenges the traditional positivist research culture. Recognizing teachers' research role is considered a pivotal factor when it comes to linking teaching practices to inquiry and reflection, yet this notion has encountered several constraints (Biesta, 2007).

There have been several initiatives on teacher research, and most of them have suggested collaborative university-schools research as a fruitful form for incorporating research on teachers' work (Christianakis, 2010; Cloonan, 2019). In this article, we focus on how collaborative research-practice partnerships (RPPs) between school and university foster teachers' role as researchers. Building on the perspectives of teachers who undertook research projects in RPPs with a Chilean university, we reflect on the benefits, challenges and tensions that emerged from this process, and propose recommendations for further teacher research projects, aiming to strengthen teachers' research role.

\section{Teachers doing research}

There is a broad tradition linked to teachers doing research, from which the potential benefits of research conducted by them have been recognized, as well as the inherent complexities of teaching. Dewey's remarks on the intrinsic relation between research and reflective thinking sparked many considerations about teaching as intrinsically research based (Rolfe, 2014). Similarly, Giroux (1988) and his perspectives on teachers as intellectuals aimed to recognize teaching as a tangled union of reflection and action and gave rise to thinking about teachers as transformative actors. Cochran-Smith and Lytle $(1992,1999)$ established solid understanding of teachers' inquiry stance and inspired many teacher research initiatives, resulting in a body of literature reflecting on the obstacles surrounding this mode of research (Storm, 2016). Based on these perspectives, it could be argued that teacher researcher is a means of acknowledging the inherent inquiry component that is part of everyday teaching, and to take it to the next stage by incorporating systematization as a process of organization, interpretation and presentation in a communicative sense of the lived experience (Freire, 1970).

Nonetheless, experiences in research conducted by teachers have not necessarily been based on the same principles and aims. There are different reasons why teachers should engage in research projects and what their role should be in this. Common justifications rest on the practice enhancement that comes from teacher research, where both teaching and learning improve substantially (Manfra, 2019; Schiera, 2014; Ulla et al., 2017). Teachers engage in systematic pedagogical reflection processes and learn through the development of a deep understanding of their pedagogy and its impact on their students' learning, allowing teachers to formulate meaningful questions for their classrooms, rather than simplistic answers (Kincheloe, 2003). Consequently, a common 
type of teacher research is action research (Reason and Bradbury, 2008; Manfra, 2019). In a similar way, teachers' professional development is considered another powerful reason for teachers' research, since conducting research has a great positive impact on teachers' progress and learning of their everyday professional practice (Ulla et al., 2017), and unsurprisingly it has been incorporated as part of development and training teaching programmes (Cochran-Smith and Lytle, 1999; Ulla et al., 2017; Cloonan, 2019).

Moreover, many have pointed out that there is a large gap among policymaking, educational research and educational practice, and that traditional research models have been more likely to maintain this gap (Biesta, 2007; Wyse et al., 2018). Policy initiatives and educational research do not have the expected impact (OEl, 2015) and, therefore, actors coming from these fields frequently agree on the existence of this gap and the dilemma of moving research to practice (Cisternas, 2011; Pesti et al., 2018; Penuel et al., 2015). Teacher research, then, has been seen as a mechanism to connect different dimensions involved in education, frequently with an emphasis on putting to work the contributions from scholars and policymakers.

Conversely, others have highlighted education research itself as a motor for taking seriously teachers' research. For Kincheloe (2003), teachers can offer significant contributions to research that would remain hidden for 'expert' university researchers, and research developed by teachers aims to achieve educational rigour and quality of education. Teachers are constantly seeking to understand what is behind their students' attitudes, developing a unique knowledge (Storm, 2016; Schiera, 2014). Kincheloe (2003: 36) has suggested:

University researchers observe for brief moments and administer problemriddled tests to measure student progress. The focus is far too simple, much too narrow, the observation much too short and devoid of context to understand the dynamics of the classroom, not to mention prescribing generalizable procedures for effective teaching.

This perspective has encountered contestation from scholars closer to traditional positivist research perspectives. Cochran-Smith and Lytle (1999) referred to these inquisitive voices as the knowledge critique, which is founded on the basis that there are different forms of knowledge - theoretical, scientific and more practical - but knowledge produced by teachers' research is typically required to be circumscribed into scientific knowledge in order to be considered valid. However, other critiques have come from scholars coming from teacher research movements, who question the purpose of this research and call to pay attention to the historical and political roots of this movement, which may have been put aside (Cochran-Smith and Lytle, 1999; Kincheloe, 2003).

Current studies have found in teachers' research a form to develop a way for teachers to collect evidence that will inform educational policies (Babkie and Provost, 2004). This focus on evidence collection reflects that not every initiative surrounding teachers' research might recognize teachers as pivotal producers of educational knowledge (Biesta, 2007; Kincheloe, 2003). Some approaches to teacher research are more likely to aim for classroom effectiveness, whereas those approaches founded in the inherent role of teachers as researchers (Giroux, 1988; Cochran-Smith and Lytle, 1992; Storm, 2016) do not see this type of research as a solution to fixed problems, but as an intrinsic component of teaching practice and as part of the inextricable link between education and inquiry.

If teachers merely apply knowledge created elsewhere, they may become deprofessionalized (Kincheloe, 2003; Giroux, 1988, 2013). This is relevant given the current 
culture of accountability and standardization, where teachers in many parts of the world are relegated to a technical role that undermines their reflexivity, autonomy and inquiry (Giroux, 2013; Biesta, 2017). It is, then, not a surprise that, even though several benefits have been described as crucial for teachers' practice, teaching models disconnected from practitioner inquiry tend to persist (Schiera, 2014), and teachers are not only reluctant to conduct their own research but also to participate in others' projects or to use research findings in their classroom (Richard and Bélanger, 2018). This issue certainly raises questions of how pertinent education research is without a dialogue with teachers. In addition, even in cases where teachers have had positive conceptions about research as a means of improving students' learning, they still might decide not to undertake research because of constraints linked to lack of research skills, intense workloads and lack of support (Schiera, 2014; Ulla et al., 2017; Cloonan, 2019).

Recognizing teachers' role as researchers is considered a pivotal factor when it comes to linking teaching practices to inquiry and reflection (Kincheloe, 2003). But there are innumerable challenges that must be addressed for teachers' research to be both legitimate and a basic element of their practice. Potential solutions could be found in the role of research communities and collaboration (Cochran-Smith and Lytle, 1992; Cloonan, 2019), which have resulted in positive experiences in confronting traditional education research approaches, namely: the Cambridge, School Teachers and Research (CamStar) project, and the School-University Partnership for Educational Research (SUPER) partnerships at the University of Cambridge, and the Knowledge Network for Applied Education Research (KNAER) at the University of Toronto. In particular, recent literature has highlighted research-practice partnerships as a potential framework for developing this form of collaboration (Furlong and Oancea, 2005; McLaughlin and Black-Hawkins, 2007; Penuel et al., 2015).

\section{Collaborative research and research-practice partnerships}

In order to understand, transform and produce knowledge about educational realities, it is necessary to build bridges between different actors and worlds involved in education, starting from an orientation of change with others (Reason and Bradbury, 2008). Recommendations to address the educational gap between teachers and research have consistently pointed to a reconceptualization of the university-school link (OEl, 2015). Academia has tended to view teachers mainly as informative actors of educational research and school problems (Beycioglu et al., 2010; Christianakis, 2010), yet the involvement of teachers in research plays a key role in generating research knowledge.

Consequently, the collaborative research-based approach becomes potentially useful and has gained ground from diverse contexts, aspirations, and methodological and theoretical orientations. It has been approached with different labels: action research, associative research, practitioner research, collaborative inquiry, critical inquiry, classroom research, inquiry-oriented teacher education, among others (Guerrero et al., 2019). In particular, research-practice partnerships between the university and the school have become a prevalent approach. In general terms, these are long-term collaborative partnerships between practitioners and university researchers that are organized to investigate problems, contributing to more robust educational theory and practice for improving schools and school districts (Coburn and Penuel, 2016). An RPP can potentially enhance the role of teacher as researcher and facilitate the professional development of both pre-service teachers and in-service 
teachers (Cheng and So, 2012). This approach seeks to challenge research in education by reconfiguring the role of the university researcher and fostering teachers' leading role in their professional development.

University staff might provide a range of research expertise, training and resources to support teacher inquiry activities, but it is the teachers who ensure that the findings are translated into schools (McLaughlin and Black-Hawkins, 2007). Thus, the alliance between the university and the school also allows us to understand research as a facilitating tool in the construction, elaboration and validation of knowledge. Moreover, this type of research constitutes an opportunity to link teachers in processes that move from reflection on practice to description, analysis and finally to action (Gray and Campbell-Evans, 2002).

However, bridging the school-university divide implies acknowledging how teachers are viewed during the process of doing research in education. Indeed, this approach demands a new configuration that breaks with the vertical relationships between university researcher and teacher, and where the teachers, no longer mere receptors, are now teacher researchers in dialogue with the university researcher, creating together new knowledge (Freire, 1970).

In addition, forming RPPs is not an easy task, and it requires addressing the cultural and political differences between the work of teachers and university researchers. Some of these differences are linked to dissimilarities in the ways that university researchers and in-service teachers tend to frame and deliberate about problems and the design of solutions to problems of practice with colleagues (Reiser et al., 2000). These differences are associated with the expected pace of work and accountability measurement of demands at work (Coburn et al., 2010). For instance, normally in-service teachers feel a strong sense of urgency; they want solutions quickly so that they can put new innovations in the curriculum or new policies in place to meet students' needs now. By contrast, research and university researchers often proceed gradually, prioritizing the production of data and evidence, then analysing through cycles of inquiry, and finally being able to recommend action (Penuel et al., 2015).

However, some limitations to this approach are based on the fact that schools and universities cannot fully change their cultures, nor can university faculty become full members of school faculties, and vice versa. This limitation could be tackled from Freire (1970) and his awareness of the dialectic within dichotomies of research-practice and knowledge through blurring the boundaries between university researcher and teacher. Developing this dialectic requires acknowledging teachers' perceptions of RPPs and creating suitable conditions, including trust, mutual respect, motivation, resources and adequate time spent in the situational context (James and Augustin, 2018).

Cochran-Smith and Lytle (1992) argued that the knowledge needed for teachers to teach well cannot be generated solely by university researchers and then transmitted for implementation into schools and classrooms. Furthermore, they argued that teachers should be positioned as researchers who develop knowledge to improve practice, while simultaneously challenging existing knowledge and the power hierarchies that are often perpetuated by universities.

Engaging in collaborative practitioner inquiry projects that involve universityschool partnerships requires the willingness to open a generative new culture, called the third space (Bhabha, 1994), which might allow the negotiation of personal ways of knowing, as well as collaborative understandings in the research process. Here, we argue that the acknowledgement of the key concept of boundary crossing and boundary practices can enrich the understanding of the interactions of research 
and practice, particularly in the context of research-practice partnerships (Penuel et al., 2015). We suggest that the collaborative work of partnerships requires both participants to engage in boundary crossing, but also closer attention to how RPPs between university and schools view the role and voice of teachers in the design and development of these initiatives.

The study aims to answer the following research question: How does a collaborative research-practice partnership between schools and universities in Chile foster teachers' role as researchers?

\section{Methodology}

This study is framed as a qualitative approach and an interpretative-comprehensive design, which is characterized by inquiry into the perceptions of the participants, and it aims to understand the particularities of the research context (Flick, 2007). The instruments to evaluate the experience consisted of an open-response questionnaire answered by 30 teacher researchers, which aimed to collect perceptions about the experience of doing collaborative research, and on focus groups involving 42 teacher researchers, which aimed to complement and expand responses from the questionnaires. Both instruments were answered voluntarily by teacher researchers who participated in establishing the RPPs within seven collaborative projects. The RPPs involved 15 university researchers from a Chilean public university and 67 members of seven schools from Chile, including in-service teacher researchers, head teachers and school principals.

Thematic analysis guided the analysis of teacher researchers' perceptions, following an inductive process and the phases of thematic analysis proposed by Braun and Clarke (2006). The phases to analyse the data were: (1) familiarizing with the data; (2) generating initial codes; (3) searching and reviewing for themes; (4) defining and naming themes; and (5) producing a report. NVivo 12 software was used for themes codification and as a tool supporting the process of analysis.

\section{Developing research-practice partnerships}

This study is part of a project implemented by a public university in Chile, which aimed to strengthen both initial teacher education and continuous professional development of in-service teachers. This project sought to question traditional ways of doing research, transitioning gradually from a vertical, hierarchical model to a horizontal, collaborative model, where teacher researchers are viewed as agents in alliance with university (see Figures 1 and 2).

The RPPs developed in this project aimed to: (1) foster a dialogue between the different actors from university and schools, building complex and multidimensional diagnoses of problems emerging from school contexts; (2) promote and develop projects based on collaborative research among communities, in particular, between in-service teachers and university researchers; (3) encourage teachers to become teacher researchers, instead of relying solely on university experts to provide solutions to their problems; and (4) strengthen and build bridges between different educational actors to promote solid processes of pedagogical reflection and collaborative work. The RPPs in this study were developed according to the stages shown in Figure 3.

The RPPs were carried out for a one-year period. The first stage involved an open call for school-based research proposals directed to a network of schools linked to the university. In particular, the university asked the schools to develop a diagnosis 


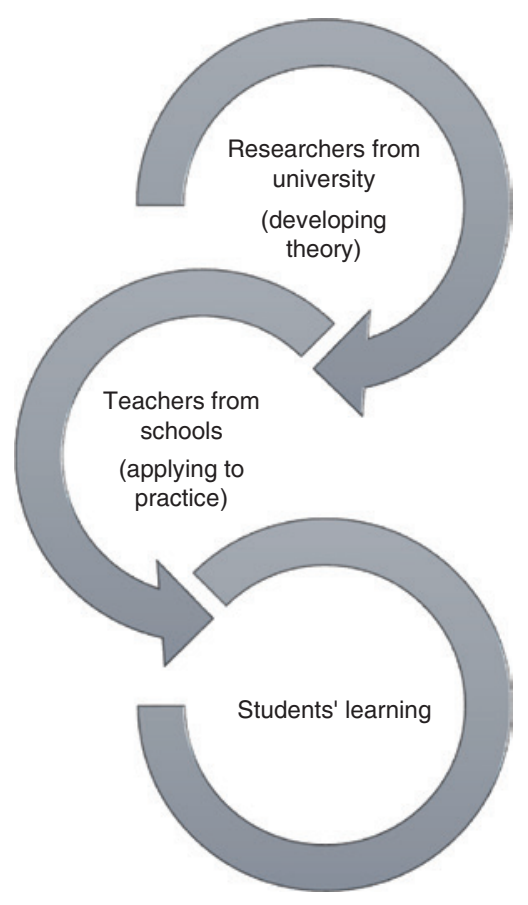

Figure 1: Modes of interaction between university and teachers doing research: vertical or traditional model of doing research

Source: Adapted from Chow et al. (2015)

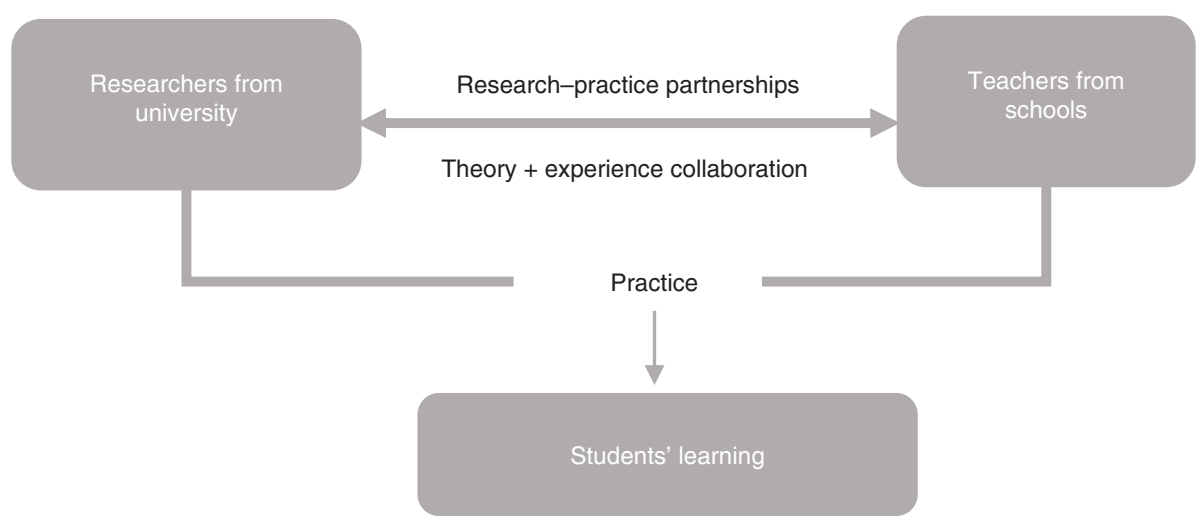

Figure 2: Modes of interaction between university and teachers doing research: horizontal model within research-practice partnerships

Source: Adapted from Chow et al. (2015)

and formulate a problem based on everyday school-life issues that they encounter, and that would contribute to their students' learning processes. A committee established by university researchers selected school applications based on the researchers' expertise and affinity with the topics.

The second stage was focused on the design of projects through collaborative work. Teacher researchers selected the methods and research approaches according to their specific contexts and the nature of their research problems. For instance, in three of the projects, the researchers used surveys and implemented focus groups with the students, who were considered the main beneficiaries of the research. All the projects were framed on action research based on a participatory action-inquiry approach (see Table 1). During this stage, university researchers provided information and literature to support the projects in dialogue with teacher researchers, who were 


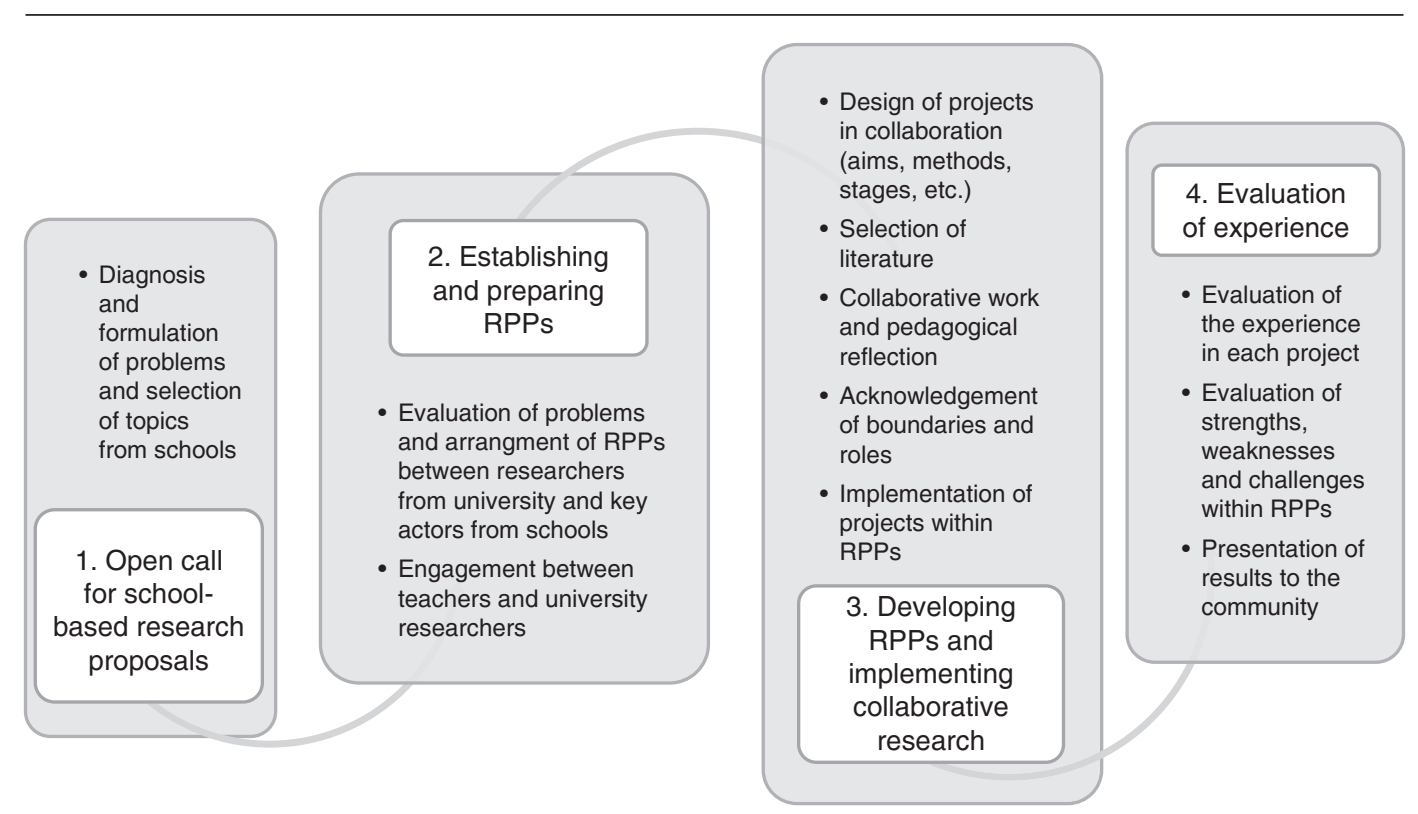

Figure 3: Research-practice partnerships and collaborative research stages

thrilled to read about their topics from academic literature. Indeed, many of them engaged critically with it when selecting the most appropriate research approach. The development of the projects comprised several meetings for pedagogical reflection and collaboration among RPPs. Furthermore, RPPs convened meetings to define roles, design instruments and to define strategies to carry out and assess each project. At the end of each project, a questionnaire was voluntarily answered by 30 participants, and focus groups, lasting about two hours each, were developed in three schools, involving 42 participants in total. The focus groups were conducted by university researchers in order to complement the number of respondents from the questionnaire, and to expand upon teacher researchers' perceptions about the process of doing collaborative research within RPPs. Survey questions in the questionnaire considered strengths, weaknesses and challenges of developing school-university collaborative research. In addition, teacher researchers' answers included suggestions of how to make improvements for a future collaborative research experience.

\section{Findings}

In this section, we aim to answer our research question regarding the extent to which collaborative research-practice partnerships between school and university foster teachers' role as researchers. We present the findings under three themes, drawn from the theoretical framework and the thematic analysis. These are: (1) the roles and constraints within the RPPs; (2) the process of conducting educational research; and (3) the relationship between RPPs and teaching practice.

\section{Roles and constraints within the research-practice partnerships}

The process of conducting research in an RPP encountered several constraints from teacher researchers' perspectives. Building from this, in this section, we problematize the role of the participants, and discuss the constraints that were pointed out by most of the participants as weaknesses and aspects to improve for a further project. In particular, time appears to be one of the major constraints for conducting the research 


\begin{tabular}{|c|c|c|c|}
\hline Name of project & Topic & $\begin{array}{l}\text { Research } \\
\text { approach }\end{array}$ & Participants \\
\hline $\begin{array}{l}\text { 1. The challenge of } \\
\text { pedagogical reflection: } \\
\text { a diagnosis of the } \\
\text { competences and } \\
\text { practices among } \\
\text { teachers }\end{array}$ & $\begin{array}{l}\text { Pedagogical reflection } \\
\text { assessment }\end{array}$ & $\begin{array}{l}\text { Action } \\
\text { research }\end{array}$ & $\begin{array}{l}\text { Head teacher of school } \\
10 \text { schoolteachers } \\
3 \text { university researchers }\end{array}$ \\
\hline $\begin{array}{l}\text { 2. Strengthening } \\
\text { collaborative strategies } \\
\text { to improving assessment } \\
\text { processes: an associative } \\
\text { research experience }\end{array}$ & $\begin{array}{l}\text { Collaborative work } \\
\text { Pedagogical reflection } \\
\text { assessment }\end{array}$ & $\begin{array}{l}\text { Action } \\
\text { research }\end{array}$ & $\begin{array}{l}\text { Head teacher of school } \\
15 \text { schoolteachers } \\
3 \text { school principals } \\
4 \text { university researchers }\end{array}$ \\
\hline $\begin{array}{l}\text { 3. Interdisciplinary } \\
\text { learning communities: } \\
\text { how to strengthen } \\
\text { teaching and } \\
\text { learning through the } \\
\text { development of thinking } \\
\text { skills }\end{array}$ & $\begin{array}{l}\text { Thinking skills } \\
\text { Interdisciplinarity } \\
\text { Collaborative work }\end{array}$ & $\begin{array}{l}\text { Action } \\
\text { research }\end{array}$ & $\begin{array}{l}\text { Head teacher of school } \\
5 \text { Schoolteachers } \\
2 \text { university researchers }\end{array}$ \\
\hline $\begin{array}{l}\text { 4. Educational practices } \\
\text { in the development of } \\
\text { mathematical skills: } \\
\text { an analysis of } \\
\text { assessments practices }\end{array}$ & $\begin{array}{l}\text { Assessment } \\
\text { Mathematical skills }\end{array}$ & $\begin{array}{l}\text { Action } \\
\text { research }\end{array}$ & $\begin{array}{l}\text { Head teacher of school } \\
2 \text { school principals } \\
10 \text { schoolteachers } \\
3 \text { university researchers }\end{array}$ \\
\hline $\begin{array}{l}\text { 5. Interdisciplinary field } \\
\text { trips: didactic routes } \\
\text { towards learning based } \\
\text { on university-school } \\
\text { associative research }\end{array}$ & $\begin{array}{l}\text { Interdisciplinarity } \\
\text { Collaborative work } \\
\text { Learning outside the } \\
\text { classroom }\end{array}$ & $\begin{array}{l}\text { Action } \\
\text { research }\end{array}$ & $\begin{array}{l}\text { Head teacher of school } \\
3 \text { school principals } \\
7 \text { schoolteachers } \\
2 \text { university researchers }\end{array}$ \\
\hline $\begin{array}{l}\text { 6. Diagnosis of reading } \\
\text { proficiency and a } \\
\text { proposal to support } \\
\text { reading comprehension }\end{array}$ & $\begin{array}{l}\text { Reading proficiency } \\
\text { Reading } \\
\text { comprehension ability } \\
\text { Collaborative work }\end{array}$ & $\begin{array}{l}\text { Action } \\
\text { research }\end{array}$ & $\begin{array}{l}\text { Head teacher of school } \\
3 \text { schoolteachers } \\
2 \text { university researchers }\end{array}$ \\
\hline $\begin{array}{l}\text { 7. Interdisciplinary } \\
\text { classroom learning in } \\
\text { contexts for the } \\
\text { appraisal of local } \\
\text { culture and care for the } \\
\text { environment }\end{array}$ & $\begin{array}{l}\text { Interdisciplinarity } \\
\text { Multicultural and } \\
\text { environmental } \\
\text { education }\end{array}$ & $\begin{array}{l}\text { Action } \\
\text { research }\end{array}$ & $\begin{array}{l}\text { Head teacher of school } \\
2 \text { schoolteachers } \\
2 \text { university researchers }\end{array}$ \\
\hline
\end{tabular}

projects, and most of the teacher researchers complained about the limited time that they could dedicate to these research initiatives.

Moreover, the answers of some participants also linked time constraints to the organizational culture of their school, where they lack the necessary time for undertaking research projects with the university. As the following quotation exemplifies, the school calendar seems to be already limited, and these research activities - which emerged as external to this calendar - are potentially problematic for in-service teacher researchers:

I suggest that they meet the times and activities following a rubric presented to us - the teachers - since by the end of the school year we have less time for improvisations. (Participant 19, Project 3) 
In addition, the research relationship is mentioned from both positive and negative angles. Regarding the former, some participants highlighted the commitment and sense of collaboration of the university researchers. Regarding the latter, other participants identified university research staff as failing to meet their plans and not giving clear information about the associated activities; in addition, some participants referred to their failure to comply with the project calendar.

Overall, and moving beyond these organizational aspects of the RPP, findings suggest that there is no unique or totally coherent view of teacher researchers' or university researchers' roles. Some teacher researchers demanded more structure and clarity from the university, whereas others thanked the university team for their clear guidance during the research, especially when they were asked about their perceptions of the relationship with the university researchers within the RPP, as these two quotations indicate:

I would have liked to have a guideline to follow and more supervision from the university researchers. (Participant 25, Project 5)

It would have been good if you'd told us how we were doing because that's what I think you [university researchers] are here for. (Participant 18, Project 4)

At the same time, and conversely, some of the teacher researchers also saw as a weakness the way in which university researchers approached their role. One participant said:

I suggest no explanatory sessions, since some of the university researchers were limited in giving a presentation on assessment theories. (Participant 10, Project 2)

In this quotation, the teacher researcher is complaining about how some university researchers used the sessions only to explain about the topic of the research from an 'expert' viewpoint, and that the sessions lacked group dialogue on the subject.

However, findings also suggest that teachers' and university researchers' knowledge is positioned and valued differently. The basis of the negative or positive evaluation that teacher researchers made about the university staff is related to dimensions of knowledge. Some of them demanded more support from the university and more practical knowledge from university researchers for their classroom practices.

Although the participants who provided the following two quotations do not share a positive evaluation of the work conducted with the university researchers, they both seem to position academic knowledge as something produced on a high and abstract level, which could improve their work if it 'came down' to schools:

I highlight the good disposition of the university researchers, who came down from theory to the reality of our establishment, through active participation in dialogue, fostered in a collective way. (Participant 11, Project 6)

I suggest complementing conversation and reflection meetings with proven educational proposals, which can then be easily applied. (Participant 17, Project 3)

In addition, when teacher researchers were asked to describe their role, they referred to detailed practical actions, such as collecting questionnaires, designing activities and participating in meetings, as can be seen in these two quotations: 
My profile was mostly technical, since I had to organize some activities, offer support to the group regarding the documents and tools that will be used in the research. (Participant 2, Project 1)

In the project carried out with university researchers, I participated basically by completing surveys, attending interviews, participating in meetings and allowing my classes to be recorded and analysed by the university researchers. (Participant 15, Project 2)

\section{Process of conducting educational research}

A second thematic focus that emerged from the participants refers to the conceptualization of research itself in the RPP, its purposes and ways of being conducted. Teachers' answers on research had a practical dimension, oriented towards action. Even though teachers connected the development of this kind of project with pedagogical reflection, they also connected research with the improvement of their teaching practices, and in some cases, they considered the research as practical knowledge that could solve problems or flaws with planning, evaluation and the implementation of activities in the classroom.

The practical knowledge gained through research does not appear only as a tool to improve, it appears as a tool to access reality in the classroom. However, this reality is presented as a problematic context, and again the aim of conducting research is to change, improve and enrich teaching practices:

One of the most valued aspects of this process was the potential for being able to access the reality of our day-to-day life in the classroom, a reality that presented difficulties, but there was no time to work on it through research ... It allowed us to observe the problem and be able to analyse it, to enrich our methodological practices, strategies and our assessment instruments. (Participant 28, Project 6)

However, teacher researchers described the purposes of their research projects only in relation to their corresponding research objectives, instead of in relation to larger purposes that exceed their school settings.

\section{Relationship between research-practice partnerships and teaching practice}

Finally, teacher researchers emphasized the relevance of pedagogical reflection for their everyday practice. Reflection is something that helps them to improve their teaching and therefore is potentially beneficial for their students. In this sense, as previously mentioned, reflection is among the more common themes underlined by the participants when they described their roles and tasks undertaken during the research:

It has been very useful to participate in this [research] project since teaching reflection is not an easy task, nor easy to develop, and analysing my pedagogic practices and correcting potential mistakes will help to improve the learning processes of my students. (Participant 1, Project 1)

Pedagogical reflection appears mainly not as a continuous process, but as a particular action that took place in relation to the implementation of the RPP initiative, and it had a defined time and space in which to be undertaken. In this sense, some of the participants alluded to reflection as being separate from their teaching inside 
the classroom, only occurring in 'meetings of pedagogical reflection'. Only some of the teacher researchers presented reflection as a process that occurred outside the predetermined time of the RPP tasks, becoming a habitual way of thinking about their professional practice. It is worth mentioning that this reflection is characterized as both an individual and a group process, depending on the participant, and on the nature of the task they describe as being their participation in the project:

This project was an example of debate and pedagogical reflection that allowed me to analyse my assessment process and improve this, built on our discussion. (Participant 7, Project 2)

Linked to aspects of pedagogical reflection, almost all the participants refer to collaboration among their peers and, to a lesser extent, between themselves and university researchers. Some participants emphasized community building as an associated aspect of collaboration within the framework of RPP. For instance, one participant mentioned that:

This has been an instance of teamwork, where knowledge and experiences among colleagues from different subjects have been shared; these were of great value during the execution of the different stages of the project. (Participant 22, Project 5)

Similarly to reflection, collaboration also seems to be highly appreciated by teacher researchers, but rarely implemented in their schools. They see collaborative work as a positive element to incorporate within the school organization; likewise, most of them declared that this way of approaching their work allowed them to interact and share classroom experiences with other in-service teachers in their schools, and also with researchers from the university:

Even though the school assigns a certain number of hours for teachers' meetings, there is not always space for pedagogical reflection and to work on unifying our criteria. This research gave us opportunity and space to get to know the work of our colleagues in detail, and also to gain the opinion and support of the experts. To sum up, the whole school community added great value to the research experience, especially when we thought about terms such as inclusion. (Participant 18, Project 2)

\section{Discussion}

Overall, even though the literature about the development of partnerships has shown positive outcomes (Coburn and Penuel, 2016), there are few studies investigating the process, organization and material conditions of carrying out RPPs in education. In this context, this study contributes to highlighting the importance of attending to the voices of teacher researchers, and to recognizing key factors during the planning of RPP activities. For instance, the time factor was considered crucial to the development of these research projects. Adhering to the calendar was highly valued among teacher researchers, who argued that they did not have time for 'improvisation' in the school. Therefore, the organization, plan of action and procedures are seen as essential elements. However, following and marking all the stages might mean that the relationships between researchers from university and from school have been constituted in an asymmetrical way, where the role of teacher researchers appears to be less active. Moreover, this could imply that instructions and guidelines might come only from external actors who manage the 
process. Thus, the development of RPPs could be considered within a vertical model between schools and universities.

In relation to this, a second element is how knowledge is conceptualized by the actors involved in the RPP. According to previous literature, different knowledges may enter into conflict in terms of hierarchies during the research (Cochran-Smith and Lytle, 1999; Schiera, 2014). In the present study, teacher researchers' knowledge was closer to a practical and concrete dimension, and most of them described their role as having a secondary status, whereas university researchers were seen as the experts who brought scientific and theoretical knowledge. Teacher researchers did not only make a distinction between the two ways of knowing, they also positioned university researchers' knowledge as superior and more valid for the research projects. Therefore, although in-service teachers developed their capacity as co-inquirers both individually and collectively, cultural boundaries ought to be openly explored before a project and explicitly agreed with them (Penuel et al., 2015). The first stages of the RPP only consider dialogue in a logistical way, not in terms of identities and positionality as an opportunity to talk about how each actor sees themselves and sees others, also navigating how personal experiences and positions are put into play in the research process.

Overall, the development of collaborative research projects implies the recognition of different professional backgrounds and identities, and also a resignification of ideas such as 'participation', 'action' and 'research', which can bring possibilities for university community members (Santos, 2016). Specifically, the research-practice partnerships revealed a series of challenges in terms of articulation, recognition of boundaries and definition of roles (Penuel et al., 2015). The roles of inservice teachers doing research have often been defined as participants who are either only providers of information, or receptors and translators of the findings of research into practice (Kincheloe, 2003; Christianakis, 2010; OEl, 2015).

Pedagogical reflection and collaboration were among the topics often highlighted by teacher researchers. In the research projects in this study, RPP opened spaces of reflection and collaboration among in-service teachers, which are foundational aspects for recognizing and developing teacher research (Kincheloe, 2003). For some teacher researchers, this facilitated a positive attitude to research, and they identified concrete benefits for their practice, as indicated by previous studies (Cloonan, 2019; James and Augustin, 2018). Nevertheless, the participants recognized university researchers as being responsible for opening spaces for pedagogical reflection, and, hence, teacher researchers viewed research as something that was not part of their everyday work. This raises the question of how teachers can continue to develop these practices once partnerships are finished.

In addition, teacher researchers valued carrying out research projects because they considered it as an opportunity to improve technical aspects of their practice and address their perceived weaknesses, rather than positioning themselves as teaching experts. This is consistent with Kincheloe (2003), who suggests that not all experiences of teacher research challenge teachers' role as technicians. Therefore, further initiatives aiming to promote teachers' empowerment through research should take account of this.

Considering these factors, findings from this study suggest that researchpractice partnerships between schools and universities foster teachers' role as researchers in different ways. On the one hand, RPPs facilitated conditions for teacher research, for instance, through pedagogical reflection, which the teacher researchers in this project pointed out as a crucial aspect in fostering them as 
researchers. On the other, there might be a predetermined intention from the university to position in-service teachers as expert researchers, considering them, again, as mere objects without a real dialogue and understanding of their work. Thus, carrying out research with others means that they are engaged as full human beings, and the collaborative process is based directly on their understanding of their own actions and experience, rather than filtered through an outsider's perspective (Reason and Bradbury, 2008).

Freire (1970) argued that doing research about the teaching profession means investigating practitioners' thinking about reality and their actions and beliefs, which is their praxis. Precisely for this reason, RPPs will benefit from considering and proposing methodologies based on dialogue and mutual deference.

\section{Conclusion}

Based on teacher researchers' perceptions about conducting research, we explored the role of collaborative research-practice partnerships in promoting teachers' role as researchers.

We highlighted the importance of considering the teacher researchers' voices, since the acknowledgement of the professional and cultural boundaries when inservice teachers participate in research-practice partnerships is crucial. Because the process of collaboration must recognize and deal with the complexity of cultural and professional boundaries, we consider that RPPs between schools and universities might enable recognition of the inherent inquiry component within teaching practice. In this study, RPPs were highly valued by teacher researchers because their research activities appear to be potential tools to develop pedagogical reflection and to generate collaborative work among colleagues towards the improvement of their practices and students' learning.

However, RPPs require awareness of multiple dimensions, such as knowledge hierarchies, role recognition, and the relationship between practical and theoretical knowledge. Moreover, organization, material conditions and time are key factors to consider in planning research activities in RPPs. Thus, further research might consider university researchers' voices and perceptions of RPPs to complete the picture, and to strengthen projects framed on action research that bring together action and reflection, fostering teachers' research role.

\section{Acknowledgements}

The authors thank the in-service teacher researchers and university researchers who participated in the research-practice partnerships and generously shared their perceptions and experiences for this study. We are also grateful to the two anonymous reviewers for invaluable feedback.

\section{Funding}

This research received funding from the project Proyecto de Mejoramiento Institucional PMI USA1503: Plan de fortalecimiento de la formación inicial y continua de los profesores egresados de la Universidad de Santiago de Chile: Una propuesta para la calidad y la equidad, en el marco de las necesidades de la educación chilena, Santiago, Chile. 


\section{Notes on the contributors}

Gonzalo R. Guerrero-Hernández is a PhD student in the Curriculum, Pedagogy and Assessment Department, UCL Institute of Education, London. He has been a physics and mathematics teacher, and the coordinator of collaborative research projects at the Universidad de Santiago de Chile (USACH). He has a master's degree in research and innovation in curriculum and teacher education from the University of Granada, Spain. His work focuses on critical scientific literacy, collaborative research, interdisciplinarity and teacher education.

Rocío A. Fernández-Ugalde is an educational psychologist, with a Master's in Policy Studies in Education from UCL Institute of Education, London. She is a PhD student in the Faculty of Education at the University of Cambridge, where she is part of the culture, politics and global justice research cluster. Her work focuses on critical educational studies and teachers' work from a global and national perspective. Until 2018, she coordinated the Chilean Network of Teacher Education of State Universities.

\section{References}

Babkie, A. and Provost, M. (2004) 'Teachers as researchers'. Intervention in School and Clinic, 39 (5), 260-8. Online. https://doi.org/10.1177/10534512040390050201.

Beycioglu, K., Ozer, N. and Ugurlu, C.T. (2010) 'Teachers' views on educational research'. Teaching and Teacher Education, 26 (4), 1088-93. Online. https://doi.org/10.1016/j.tate.2009.11.004.

Bhabha, H.K. (1994) The Location of Culture. London: Routledge.

Biesta, G. (2007) 'Why "what works" won't work: Evidence-based practice and the democratic deficit in educational research'. Educational Theory, 57 (1), 1-22. Online. https://doi.org/10.1111/ j.1741-5446.2006.00241.x.

Biesta, G. (2017) 'Education, measurement and the professions: Reclaiming a space for democratic professionality in education'. Educational Philosophy and Theory, 49 (4), 315-30. Online. https:// doi.org/10.1080/00131857.2015.1048665.

Braun, V. and Clarke, V. (2006) 'Using thematic analysis in psychology'. Qualitative Research in Psychology, 3 (2), 77-101. Online. https://doi.org/10.1191/1478088706qp063oa.

Cheng, M. and So, W. (2012) 'Analysing teacher professional development through professional dialogue: An investigation into a university-school partnership project on enquiry learning'. Journal of Education for Teaching, 38 (3), 323-41. Online. https://doi.org/10.1080/02607476.2012 .668331 .

Chow, K., Chu, S., Tavares, N. and Lee, C. (2015) 'Teachers as researchers: A discovery of their emerging role and impact through a school-university collaborative research'. Brock Education Journal, 24 (2), 20-39. Online. https://doi.org/10.26522/brocked.v24i2.374.

Christianakis, M. (2010) 'Collaborative research and teacher education'. Issues in Teacher Education, 19 (2), 109-25.

Cisternas, T. (2011) 'La investigación sobre formación docente en Chile: Territorios explorados e inexplorados'. Calidad en la Educación, 35, 131-64. Online. https://doi.org/10.31619/caledu. n35.98.

Cloonan, A. (2019) 'Collaborative teacher research: Integrating professional learning and university study'. Australian Educational Researcher, 46 (3), 385-403. Online. https://doi.org/10.1007/ s13384-018-0290-y.

Coburn, C. and Penuel, W. (2016) 'Research-practice partnerships in education'. Educational Researcher, 45 (1), 48-54. Online. https://doi.org/10.3102/0013189×16631750.

Coburn, C., Stein, M., Baxter, J., D'Amico, L. and Datnow, A. (2010) Research and Practice in Education: Building alliances, bridging the divide. Lanham, MD: Rowman and Littlefield.

Cochran-Smith, M. and Lytle, L. (1992) 'Communities for teacher research: Fringe or forefront?'. American Journal of Education, 100 (3), 298-324. Online. https://doi.org/10.1086/444019.

Cochran-Smith, M. and Lytle, L. (1999) 'The teacher research movement: A decade later'. Educational Researcher, 28 (7), 15-25. Online. https://doi.org/10.3102/0013189x028007015.

Flick, U. (2007) Designing Qualitative Research. London: SAGE Publications.

Freire, P. (1970) Pedagogy of the Oppressed. New York: Continuum. 
Furlong, J. and Oancea, A. (2005) Assessing Quality in Applied and Practice-Based Educational Research: A framework for discussion. Oxford: Oxford University Department of Educational Studies.

Gandin, L. and Gomes de Lima, I. (2015) 'Reconfiguração do trabalho docente: Um exame a partir da introdução de programas de intervenção pedagógica'. Revista Brasileira de Educação, 20 (62), 663-77. Online. https://doi.org/10.1590/S1413-24782015206206.

Giroux, H. (1988) Teachers as Intellectuals: Toward a critical pedagogy of learning. Westport, CT: Bergin and Garvey.

Giroux, H. (2013) 'Neoliberalism's war against teachers in dark times'. Cultural Studies $\leftrightarrow$ Critical Methodologies, 13 (6), 458-68. Online. https://doi.org/10.1177/1532708613503769.

Gray, J. and Campbell-Evans, G. (2002) 'Beginning teachers as teacher-researchers'. Australian Journal of Teacher Education, 27 (1), Article 4. Online. https://doi.org/10.14221/ajte.2002v27n1.4.

Guerrero, G., Fernández, R. and Watson, G. (eds) (2019) Investigando Juntos: Experiencias Asociativas entre la Escuela y la Universidad de Santiago de Chile. Santiago: Editorial Usach.

James, F. and Augustin, D. (2018) 'Improving teachers' pedagogical and instructional practice through action research: Potential and problems'. Educational Action Research, 26 (2), 333-48. Online. https://doi.org/10.1080/09650792.2017.1332655.

Kincheloe, J. (2003) Teachers as Researchers: Qualitative inquiry as a path to empowerment. New York: Routledge.

Manfra, M. (2019) 'Action research and systematic, intentional change in teaching practice'. Review of Research in Education, 43 (1), 163-96. Online. https://doi.org/10.3102/0091732x18821132.

McLaughlin, C. and Black-Hawkins, K. (2007) 'School-university partnerships for educational research - distinctions, dilemmas and challenges'. Curriculum Journal, 18 (3), 327-41. Online. https://doi.org/10.1080/09585170701589967.

OEI (Organización de Estados Iberoamericanos para la Educación) (2015) Estado del arte: Investigaciones sobre formación práctica en Chile: Tensiones y desafíos. Santiago: Organización de Estados Iberoamericanos para la Educación.

Penuel, W., Allen, A., Coburn, C. and Farrell, C. (2015) 'Conceptualizing research-practice partnerships as joint work at boundaries'. Journal of Education for Students Placed at Risk (JESPAR), 20 (1-2), 182-97. Online. https://doi.org/10.1080/10824669.2014.988334.

Pesti, C., Győri, J. and Kopp, E. (2018) 'Student teachers as future researchers: How do Hungarian and Austrian initial teacher education systems address the issue of teachers as researchers?'. Center for Educational Policy Studies Journal, 8 (3), 35-57. Online. https://doi.org/10.26529/ cepsj.518.

Reason, P. and Bradbury, H. (eds) (2008) The SAGE Handbook of Action Research: Participative inquiry and practice. 2nd ed. London: SAGE Publications.

Reiser, B.J., Spillane, J.P., Steinmuler, F., Sorsa, D., Carney, K. and Kyza, E. (2000) 'Investigating the mutual adaptation process in teachers' design of technology-infused curricula'. In Fishman, B. and O'Connor-Divelbiss, S. (eds) Fourth International Conference of the Learning Sciences. Mahwah, NJ: Lawrence Erlbaum Associates, 342-9.

Richard, V. and Bélanger, M. (2018) 'Accepting research: Teachers' representations of participation in educational research projects'. International Journal of Educational Methodology, 4 (2), 61-73. Online. https://doi.org/10.12973/ijem.4.2.61.

Rolfe, G. (2014) 'Rethinking reflective education: What would Dewey have done?'. Nurse Education Today, 34 (8), 1179-83. Online. https://doi.org/10.1016/j.nedt.2014.03.006.

Santos, D. (2016) 'Re-signifying participatory action research (PAR) in higher education: What does "P" stand for in PAR?'. Educational Action Research, 24 (4), 635-46. Online. https://doi.org/10.10 80/09650792.2015.1103658.

Schiera, A. (2014) 'Practitioner research as "praxidents" waiting to happen'. Penn GSE Perspectives on Urban Education, 11 (2), 107-21.

Schön, D. (1987) Educating the Reflective Practitioner: Toward a new design for teaching and learning in the professions. San Francisco, CA: Jossey-Bass.

Storm, S. (2016) 'Teacher-researcher-leaders: Intellectuals for social justice'. Schools: Studies in Education, 13 (1), 57-75. Online. https://doi.org/10.1086/685803.

Ulla, M., Barrera, K. and Acompanado, M. (2017) 'Philippine classroom teachers as researchers: Teachers' perceptions, motivations, and challenges'. Australian Journal of Teacher Education, 42 (11), 52-64. Online. https://doi.org/10.14221/ajte.2017v42n11.4.

Wyse, D., Brown, C., Oliver, S. and Poblete, X. (2018) The BERA Close-to-Practice Research Project: Research report. London: British Educational Research Association. Online. www.bera.ac.uk/ researchers-resources/publications/bera-statement-on-close-to-practice-research (accessed 28 August 2020). 